\title{
Histopathological study on rodent small intestine infected with an adult tapeworm, Hymenolepis diminuta recorded at Sohag, Egypt
}

\author{
Ramadan S.A., Hassan A.H., Asran A.A., Abd Elgwad E.F. \\ Department of Zoology, Faculty of Science, Sohag University.
}

Rec. 15 Feb, 2016 Accept. 21 Mar, 2016

\begin{abstract}
Rodents play a significant role in public health, Chiefly due to their role as carriers or reservoirs of microbes and parasites of zoonotic importance. The main objective of the present study was to make a histopathological study on the small intestine of rodents infected with an adult tapeworm, Hymenolepis diminuta collected from two sites at Sohag, Egypt. The study revealed that The infection percentages of the present rodent with the adult tapeworm Hymenolepis diminuta were (12\% females) and (16\% males) and (12\% females) and (8\% males) in first and second sites, respectively. Histopathologically, the lumina of the present rodent intestine contained tapeworm. Presence of the tapeworm in lumina of the infected rodent intestine lead to excessive mucin secretion in luminal debris. Some intestinal villi appeared blunt and reduced in height. The intestinal muscularis layers were thickened. Moreover, inflammatory cells infiltration in the connective tissue core of the villi and crypts were observed. Erosion and adhesion of the tip of villi were observed in the intestine. The proliferating activity of the enterocytes was evidently increased and mitotic figures were observed not only in the intestinal crypts but also in the epithelium covering the middle third of the villi. Crypts and villi hyperplasia of intestine were observed.
\end{abstract}

Key words: Rodents, intestine, histopathology.

\section{Introduction}

Endo-parasites of rodents play an important role in the zoonotic cycles of many diseases. Several studies on endo-parasites of commensal and forest rodents have been carried out in Malaysia (Leong et al., 1979; Ambu et al., 1996). Studies on the endoparasites of rats have been carried out in several countries such as Malaysia (Leong et al., 1979; Chooi and Sani, 1985; Ambu et al., 1996; SyedArnez et al., 2006; Paramasvaran et al., 2009).

Mezaros et al., (1983) presented the first data on the helminth species of the house mouse and other rodents. Different authors have reported a wide range of rat helminthic parasites all over the world, (Nama and Parihar, 1976). in India, (Seong et al., 1995). in Korea, (Yen et al., 1996). in China, (Namue and Wongsawd, 1997). in Thailand, (Davoust et al., 1997) in France, (Abd el-Wahed et al., 1999). in Egypt, (Ceruti et al., 2001). in Italy, (Stojcevic et al., 2004). in Croatia, (Al-Zihiry, 2006) in Iraq and Kataranovski et al. (2010) in Serbia.

Hymenolepis diminuta is the most common of the rat tapeworms all over the world (Ahmed et al., 2015). Rats and other rodents are the definitive host, while arthropods such as fleas, Lepidoptera and coleopteran act as intermediate host (De Carneri, 2004). The occurrence of genus
Hymenolepis in wild rats was reported by (Simmous and Walkey, 1971; Gardner and Schmidt, 1988). (Joseph, 1974) reported the presence of Hymenolepis diminuta in gray squirrel from Indiana. Also, (Seong et al., 1995) and Iannacone and Alvariño (2002) studied intestinal parasites of rats. (Fagir and Rayab, 2009) described two species of cestodes, Hymenpleis nana and $H$. diminuta from Nile rats in Sudan.

Histopathologically, the tapeworm Hymenolepis diminuta is a chronic parasite living in the small intestine of rats, mice and humans (Dwinell et al., 1998; Kosik-Bogacka and Kolsaa, 2012). This tapeworm produces some pathological changes in the entire small intestine of the host such as disappearance of intestinal villus, inflammatory swelling, and small bowel erosion and reduction of height (Fal and Czaplicka, 1991). In rodents, $H$. diminuta infection results in an increase in crypt depth as well as number of goblet cells in the villus of intestinal epithelium (Mckay et al 1990; Webb et al., 2007). Also, infected rats may also have mucosal mastocytosis and smooth muscle hypertrophy (Dwinell et al., 1998). On the other hand, the presence of tapeworm Hymenolepis diminuta in rat small intestine caused reduction in intestinal permability and absorption of electrolytes 
and fluid (Podesta and Mettrick, 1974) and electrophysiological parameters (Palmer and Castro, 1986; Kosik-Bogacka et al., 2010).

The present study aims to describe the collected adult tapeworm from the caught rodents and study histopathological changes in the infected small intestine of rodents.

\section{Materials and methods:}

The present work was carried out in two trapping area, (Shandwell farm and surrounding houses, Sohag, Egypt). The study area was chosen for the present work because it is highly infested with rodents also the selected area occupied with different fruit trees (palm and mango), summer and winter field crops and vegetables

All rodents (Genus: Rattus) were trapped alive using specially made wire traps, each of which measures $(24 \times 11 \times 9 \mathrm{~cm})$ in both sites. Traps were baited with meat and carrot and sampling was carried out randomly.

50 rodents (25 individuals from each site) were caught alive from two localities in north east of Sohag city during the period of collection from May 2010 till April 2011. The collected rodents were dissected in the laboratory, and the small intestine of rodents were removed from the digestive tract, put in separate labeled Petri-dishes containing saline solution, and then examined separately under sterobinocular microscope searching for adult tapeworms.

The adult tapeworms were picked up by delicate forceps and put in another clean Petri-dish containing the saline solution. They were relaxed in cold water during 24 hours, fixed in hot alcoholformalin- acetic acid, stained with carmine stain, dehydrated in graded series of ethyl alcohol, cleared in toluene and mounted on slide with Canada balsam. After preparation of adult tapeworms for study, they were examined and measured with an ocular micrometer of Olympus microscope (mm) and photographed.

For histopathological studies, small pieces of rodent small intestine were fixed in Carnoy's fluid dehydrated in graded series of alcohols, embedded in paraffin wax, sectioned at 5-7 $\mu \mathrm{m}$ and stained with haematoxylin and eosin. The stained sections were examined under a research microscope and then photographed.

Identification of the present parasites was carried out according to the keys of Joyeux and Kobozieff (1928), Yamaguti, ( 1959), Leong et al. (1979), Miyazaki (1991) and Ambu et al. (1996) for adult tapeworm. The present host was identified by Harrison\& Quah (1962), Medway (1983) and Payne et al. (1985).

\section{Results:}

50 rodents ( 25 individuals from each site) were collected and dissected in the laboratory. Table (1) shows the number of infected organs of rodent females and males with adult tapeworm, Hymenolepis diminuta in the two sites. In the first sites, 3 individuals of rodent females (12\%) and 4 males $(16 \%)$ were infected with the adult. While, in the second sites, 3 individuals of rodent females (12\%) and 2 males (8\%) were infected with the adult tapeworm.

\begin{tabular}{|c|c|c|c|c|c|}
\hline \multirow{2}{*}{ Adult tapeworm } & Infected organ & \multicolumn{2}{|c|}{ First site } & \multicolumn{2}{c|}{ Second site } \\
\cline { 3 - 5 } & & Female & Male & Female & Male \\
\cline { 2 - 5 } & Intestine & 3 & 4 & 3 & 2 \\
\hline
\end{tabular}

Table 1: Number of infected organs of rodents with adult tapeworm, Hymenolepis diminuta in the two sites of collections.

During gross examinations, small intestine of rodents showed adult tapeworms which was described as follows:

\section{1- Scolex and suckers:}

Macroscopic and microscopic examinations of the present rodent small intestine showed presence of adult tapeworms. The number of tapeworms ranged from 1 to 9 per host. The fresh worm is white in colour, filiform and cylindrical in shape. The body of tapeworm is differentiated into an expanded anterior end, scolex bearing hold organs, un-segmented neck and strobila which is very elongated. The scolex is slightly wider than the neck with unarmed rostellum. The four suckers are unarmed simple and cup shaped (Pl. 1A, B, C).

\section{2- Segments:}

Immature, mature and gravid proglottids are broader than long. It is important to note that all hymenolepidids have a single set of reproductive organs per segments, and genital pores are unilateral (Pl. 1D).

\section{3- Male reproductive organs:}

The male reproductive organs involve three testes (one poral and two aporal) and cirrus sac. Testes are spherical in shape and located in the median field. It is noted that single poral testes 
separated by ovary from the two aporal ones. Cirrus is smooth and surrounded with an oval cirrus sac which is short and not reaching middle of segment and open into genital atrium just dorsal to the vagina (Pl. 1E, F).

\section{4- Female reproductive organs:}

The female reproductive organs involve multilobed ovary lying in the middle of segments with oval vitteline glands, an oval seminal receptacle and uterus. Uterus is a large transverse sac divided into an irregular network, and filled with spherical eggs. Eggs in all examined specimens are immature. They have two shells and without hooks. The space between the shells is filled with a loose cellular mass $(\mathrm{Pl} .1 \mathrm{G}-\mathrm{J})$.

The embryos are spherical and vary in diameter. Table (2) summarized the measurements $(\mathrm{mm})$ of adult tapeworm.

\begin{tabular}{|l|c|c|c|c|c|c|}
\hline Parameters & \multicolumn{2}{|c|}{ Minimum } & \multicolumn{2}{c|}{ Maximum } & \multicolumn{2}{c|}{ mean } \\
\hline Characters & Length & Width & Length & Width & Length & Width \\
\hline Scolex & 0.19 & & 0.24 & & 0.23 & ----- \\
\hline Suckers & 0.08 & 0.05 & 0.09 & 0.06 & 0.09 & 0.06 \\
\hline Immature segments & 0.12 & 0.7 & 0.20 & 1.4 & 0.3 & 1.15 \\
\hline Mature segments & 0.19 & 1.74 & 0.48 & 1.79 & 0.23 & 1.76 \\
\hline Testes & 0.13 & 0.13 & 0.19 & 0.15 & 0.16 & 0.14 \\
\hline Seminal receptacles & 0.19 & 0.09 & 0.26 & 0.26 & 0.22 & 0.13 \\
\hline Gravid segments & 0.29 & 2.05 & 0.67 & 2.1 & 0.48 & 2.01 \\
\hline Egg & 0.04 & 0.03 & 0.09 & 0.06 & 0.07 & 0.04 \\
\hline
\end{tabular}

Table 2: Measurements ( $\mathrm{mm}$ ) of adult tapeworm Hymenolepis diminuta.

The intestine of rodents is a long coiled tube and its wall consists of serosa, muscularis, submucosa and mucosa. These layers are arranged serially one below the other.

Histopathologically, the lumina of the present rodent intestine contained tapeworm. Excess mucin secretion were observed in luminal debris. Some intestinal villi appeared blunt and reduced in height. The intestinal muscularis layers were thickened. Moreover, inflammatory cells, infiltration in the connective tissue core of the villi and crypts were observed. Erosion and adhesion of the tip villi were observed in the intestine. The proliferating activity of the enterocytes was evidently increased and mitotic figures were observed not only in the intestinal crypts but also in the epithelium covering the middle third of the villi. Crypts and villi hyperplasia of intestine were observed (Pl. 2A-J).

\section{Disscusion:}

Hymenolepis diminuta is a cosmopolitan parasite, which has been commonly reported from the intestine of rodent hosts worldwide. The present adult tapeworm were observed in the lumen of intestine of rodents. This observation recorded by some authors such as Balachandra and Ranade (1978), Jawdat and Mahmoud (1980), Dwinell et al. (1998a, b), Webb et al. (2007), Singla et al. (2008) and Kosik-Bogacka and Kolasa (2012).

The number of infected organs of present rodent females and males with adult tapeworm Hymenolepis diminuta in the two sites reported as follows: in the first sites, 3 individuals of rodent females (12\%) and 4 males (16\%) were infected with adult cestode. While, in the second sites, 3 individuals of rodent females (12\%) and 2 males $(8 \%)$ were infected with adult $H$. diminuta. The incidence value for $H$. diminuta in different types of rodents all over the world was reported $37 \%$ and $67 \%$ in Nile delta and Upper Egypt (Fahmy et al., 1969) respectively, $41 \%$ in Suez canal (Abdel Aal. and Abou Eisha 1997), 13\% in Khuzestan (Sadjjad and Massoud, 1999), 25\% in Iraq (Al-Zihiry, 2006) and 50\% in India (Singla et al., 2008).

The tapeworm $H$. diminuta was reported in most studies done all over the world. It was recorded in Iraqi (Mahmoud, 1974; Al-Barwari et al., 1987; AlZihiry, 2002), in Thailand (Chitchang et al., 1978), Kuala lumpur ( Leong et al., 1979), USA(Levi et al., 1987), Jamaica (Cohen, 1989), Nigeria (Miafiana et al., 1997), Iran(Sadjjadi and Massoud, 1999), the Philippines (Claveria et al., 2005) and in Egypt (Mohammad and Hegazi, 2007). On the other hand, hundred cases of children have been reported in humans infections with $H$. diminuta (Levi et al., 1987; Panpiglione et al., 1987 and Cohen, 1989;).

The present tapeworm is medium in size, scolex with four suckers, rostellar hooks are absent. There are multistrobila its length is less than width 3 male reproductive organs involve three $\mathrm{sph}$....... testes, one poral and two aporal. Cirrus sac is oval. While the female reproductive organs involve multilobed ovary lying in the middle of the segments with oval vitteline glands, seminal 
receptacle oval, uterus filled with eggs. According to Hussein (1986); Macko and Hanzelova (1997); Casanova et al., (2001) and Al-zihiry (2006), the morphological characters of the present tapeworm corresponding to the adult tapeworm, $H$. diminuta .

Histopathologically, the lumina of the present rodent intestine contained tapeworm, Hymenolepis diminuta . Excessive mucin secretion were observed in luminal debris. Some intestinal villi appeared blunt and reduced in height. The intestinal muscularis layers were thickened. Moreover, inflammatory cells, infiltration in the connective tissue core of the villi and crypts were observed. Erosion and adhesion of the tip of villi were observed in the intestine. The proliferating activity of the enterocytes was evidently increased and mitotic figures were observed not only in the intestinal crypts but also in the epithelium covering the middle third of the villi. Crypts and villi hyperplasia of intestine were observed. Similar findings were reported by some authors Podesta and Mettrick (1974), Fal and Czaplicka (1991) and Kosik-Bogacka and Kolasa (2012). In rodents, $H$. diminuta infection results in increase in crypt depth and number of goblet cells in the villus of intestinal epithelium (Mckay et al. 1990; Dwinell et al 1998; Webb et al. 2007).

\section{Abbreviations:}

$\mathrm{Ad}=$ Adult of tapeworm
AT $=$ Aporal Test of adult

$\mathrm{CA}=$ Cirrus of Adult

$\mathrm{CR}=$ Crypts of intestine

$\mathrm{EA}=$ Eggs of Adult

$\mathrm{FF}=$ Fine Fragmentation

GP $=$ Genital Pores of adult

$\mathrm{HA}=$ Head of Adult

$\mathrm{HI}=$ Hepatic Inflammatory reaction

$\mathrm{HP}=$ Hyperplasia of intestine

ICI = Inflammatory cells inflitration

$\mathrm{IO}=$ Intestine Organ of rodent

IS = Inner Shell of eggs

$\mathrm{MI}=$ Mitoses of Intestine epithelium

$\mathrm{NA}=$ Neck of Adult

$\mathrm{NW}=$ Net Work reticulation of intestine epithelium

$\mathrm{OA}=$ Ovary of Adult

OS $=$ Outer Shell of eggs

$\mathrm{PT}=$ Poral Testes of adult

RA $=$ Rostellum of Adult

$\mathrm{SA}=$ Scolex of Adult

SI $=$ Stroma of Intestine

$\mathrm{SR}=$ Seminal Receptical of adult

SUA $=$ Sukers of Adult

SW $=$ Sinusoid Widening

$\mathrm{UA}=$ Uterus of Adult

$\mathrm{VA}=$ Vagina of Adult

$\mathrm{VG}=$ Vitelline Gland of adult

$\mathrm{VI}=$ Villia of Intestine

\section{List of Photos:}
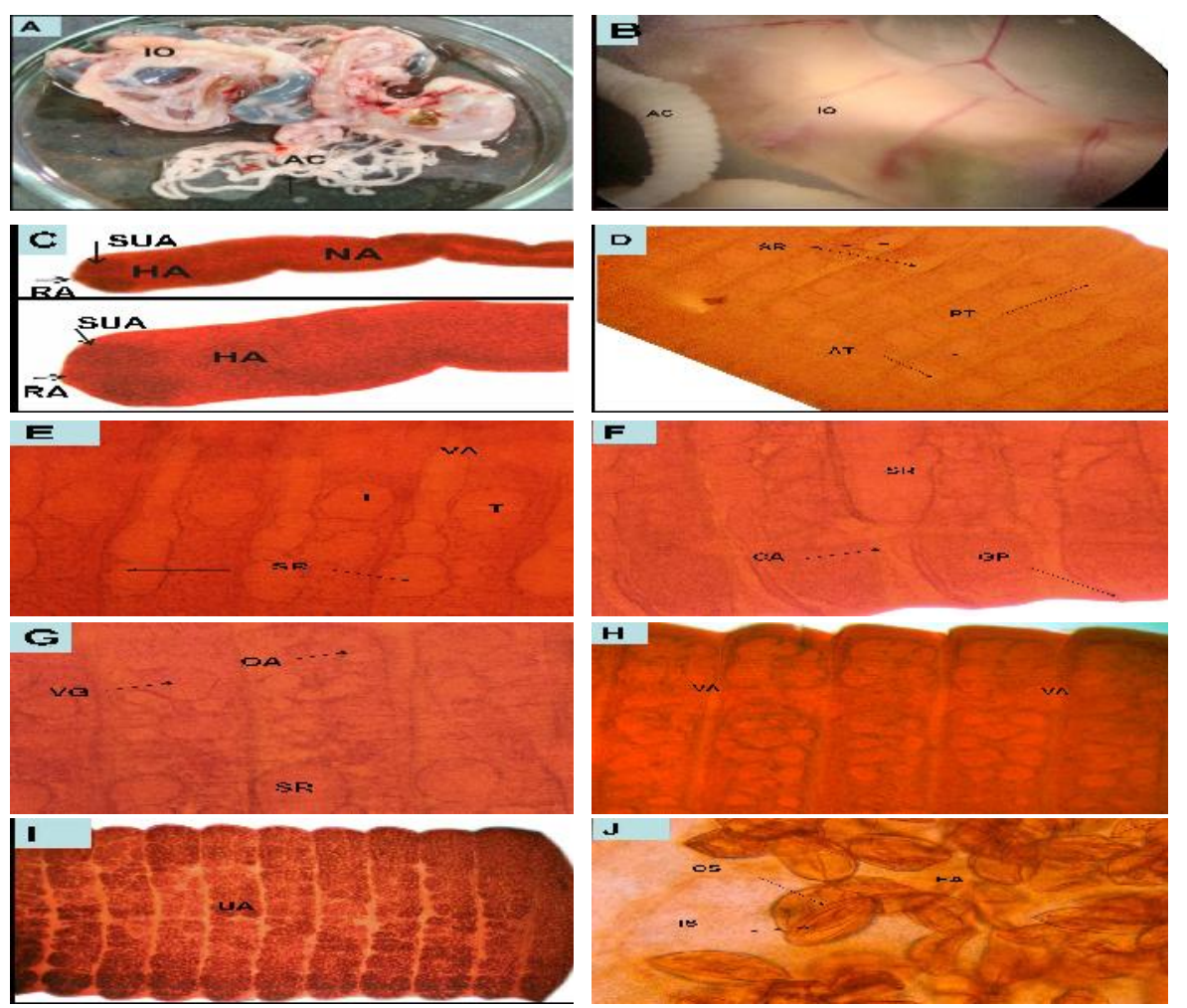

Plate 1: Photographs and Photomicrographs of dissected rodent small intestine infected with adult tapeworm, Hymenolepis diminuta showing. 

A- Adult worm inside the intestine
B- Congested intestine of rodent
C- head, neck and suckers
D- Poral and aporal testes.
E- testes, seminal receptacles and vagina of matue segments.

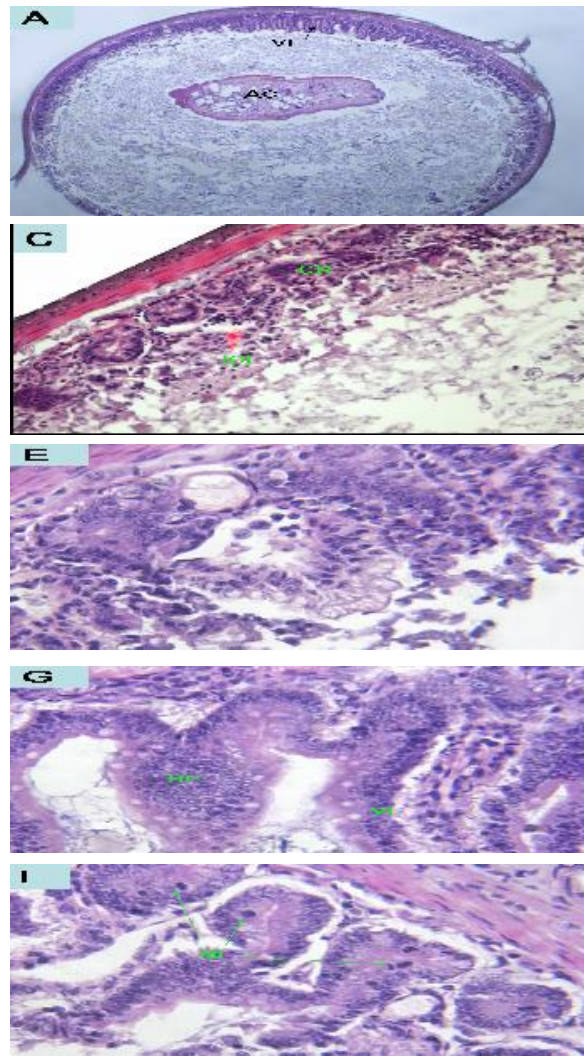

F- cirrus and genital pores.

G- ovary and vitelline gland.

H- Pregravid segments with developing reticulate uteri

I- gravid segments with developing eggs in uteri $\mathbf{J}$ - outer and inner shells of eggs

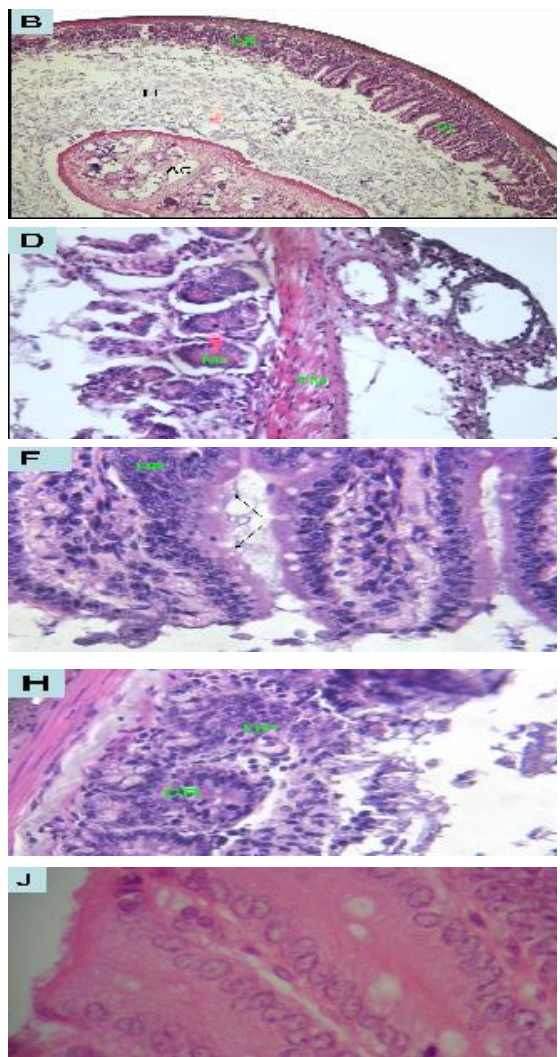

Plate 2: Photomicrographs of transverse histological sections through rodent small intestine infected with adult tapeworm, Hymenolepis diminuta showing.
A- worm inside the intestine lumen.
B- structure of intestine
C- Inflammatory cells infiltration
D- Thickened of muscular layer
E- erosion and adhesion of villi and crypts
F- brush border of villi disappeared
G- hyperplasia of villi
H- hyperplasia of crypts
I- Mitotic figures of crypts
$\mathbf{J}$ - Fusion and liquefactions of villi

\section{References:}

Abdel Aal, A.A. and Abou Eisha, A.M. (1997). The role of rats as reservoir of some internal parasites with possible public health implications in Suez Canal area. Assiut Vet. Med. J., 37: 174-185.

Abdel-Wahed, M.M., Salem, G.H. and El-Assaly, T.M. (1999). The role of wild rats as a reservoir of some internal parasites in Qalyobia Governorate. J. Egypt. Soc. Parasitol., 29: 495-503.
Ahmed, A.K., Ekhas, A., Abdel-Haffez, E.H. and Kamal, A.M. (2015): Some studies on Spontaneous Hymenolepis diminata infection in laborty Rats J. Egypt. Soc. Parasitol. (JESP). 45 (1), 2015: 115124.

Al-Barwari, S.E., Nassir, J.K. and Zaia, M. (1987). Gastro-intestinal helminthes of common rodents in Baghdad with the record of Hymenolepis diminuta from hamster. Iraqi J. Sci., 28 (2): 299-308.

Al-Zihiry, K.J.K. (2002). Helminth parasites in some small mammals from Basrah province. M. SC. Thesis, Coll. Edu., Univ. Basrah: 84 PP.

Al-Zihiry, K.J.K. (2006). Some intestinal helminthes of Norway rat Rattus norvegicus (Berkenhout, 1969) in Basrah, Iraq J. of university of thi Qar No. I Vol. 2.

Ambu, S., Krishnasamy, M., Ramachandran, P. and Ramos, R. (1996). Helminth 
infections of rodents in orang Asli settlement in Selangor, Malaysiapossible health risk . Tropical Biomedicine . 13 : 23-127.

Balachandra, D.V. and Ranade, D.R. (1978). A preliminary Survey of helminth parasites of rats from Poona City. Indian Veterinary J., 5:175-176.

Casanova, J.C., Santalla, F., Durand, P., Vaucher, C., Feliu, C. and Renaud, F. (2001). Morphological and genetic differentiation of Rodentolepis straminea (Goeze, 1752) and Rodentolepis microstoma (Dujardin, 1845) (Hymenolepididae) Parasitol Res., 87: 439-444.

Ceruti, R., Sonzogni, O., Origgi, F., Vezzoli, F., Cammarata, S., Giusti, A.M., Scanziani, E. (2001). Capillaria hepatica infection in wild brown rats (Rattus norvegicus) from the urban area of Milan, Italy. J. vet. Med B, 48, 235-240.

Chitchang, S., Sooksala, N. and Radomyos, P. (1978). A case report of Hymenolepis diminuta in Bangkok, Thailand. Southeast Asian J. Trop. Med. Pub. Hlth., 9(4): 534-535.

Chooi, K.F. and Sani, R.A. (1985). Metacestode of Taenia hydatigena recorded in Malaysia. Veterinary Record. 116 (1): 27.

Claveria, F., Causapin, J., de Guzman, M., Toledo, M. and Salibay, C. (2005). Parasite biodiversity in Rattus spp. caught in wet markets. Southeast Asian J. Trop. Med. Publ. Hlth., 36(4): S146-S148.

Cohen, I.P. (1989). A case report of a $H$. diminuta infection in a child in St James Parish, Jamaica. J. La State Med Soc., 141(3): 23-24.

Davoust, B., Boni, M., Branquet, D., Ducos de Lahitte, J. and Martet, G. (1997). Research on three parasitic infestations in rats captured in Marseille: evaluation of the zoonotic risk. Bull . Nat. Acad. Med., 181,887-897.

De Carneri, F. (2004). Elminti. Classe cestoda. Ordine Cyclophilidae. Famiglia Hymenolepididae. Parassitolgia generale e umana. $13 \mathrm{Th}$ edition; Milano, Italy.

Dwinell, M.B., Wise, R.M., Bas, P. and Oaks, J.A. (1998). Hymenolepis diminuta; mucosal mastocytosis and intestinal smooth muscle hypertrophy occur in tapeworm-infected rats. Exp. Parasitol. 89: 92-102 .

Fagir, D.M. and El-Rayab, E.A. (2009). Parasites of the Nile rat in rual and urbon region of Sudan integrative Zoo. Zoog, 4: b179-187.

Fahmy, M., Rifaat, M.A. and Arafa, M.S. (1969). Helminthic infections of the brown rats, Rattus norvegicus. J. Egypt. Publ. Hlth. Assoc., 44: 147-153.

Fal, W. Czaplicka, H. (1991). Effect of experimental hymenolepiasis on various tissue reactions in rats. Wiad. Parazytol. 37 : 331-342 . (In Polish).

Gardner, S.L. and Schmidt, G.D. (1988). Cestodes of the genus Hymenolepis Weinland, 1858 sensu stricto from pocket gophers Geomys and Thomomys spp. (Rondentia: Geomyidae) in Colorado and Oregon, with a discriminant analysis of four species of Hymenolepis. Can. J. Zool., 66: 896903.

Harrison, J.L. and Quah, S.k. (1962). The house and field rats of Malaysia. Bull. No. 12, Inst. Med. Res. Federation of Malaya. Pp. 38

Hussein, M.M.S. (1986). Asurvey of some endoparasites of house rodents in Erbil area. M. Sc. thesis, Coll. Sci. Univ. Salah-Alden: $104 \mathrm{pp}$.

Iannacone, O.J. and Alvarino, L.F. (2002). Helmintofauna de Rattus rattus (Linnaeus, 1758) y Rattus norvegicus (Berkenhout, 1769) (Rodentia: Muridae) en el distrito de San Juan de Lurigancho, Lima-Perú. Rev. Perú Med. Experimental y Salud Pública, 19: $136-141$

Jawdat, S.Z. and Mahmoud, S.N. (1980). The incidence of cestodan and acanthocephalan parasites of some rodents in Iraq. Bulletin of the Natural History Research Centre Baghdad.7: 55-71.

Joseph, T. (1974). Hymenolepis diminuta in a gray squirrel from Indiana. Journal of wildlife Diseases. 10: 164-165.

Joyeux, C., Kobozieff, N.I. (1928). Recherches sur l'Hymenolepis microstoma (Dujardin, 1845) Annales de Parasitologie. 6: 5979

Kataranovski, M., Zolotarevski, L., Belij, S., Mirkov, I., Stosic, J., Popov, A. and Kataranovski, D. (2010). First record 
of Calodium hepaticum and Taenia taeniaeformis liver infection in wild Norway rats (Rattus norvegicus) in Serbia. Archives of Biological Sciences. Belgrade. 62(2): 431-440.

Kosik-Bogacka, D.I. and Kolasa, A. (2012). Histopathological changes in small and large intestines during hymenolepidosis in rats. Folia Biol., 60: 195-198.

Kosik-Bogacka, D., Baranowska-Bosiacka, I. and Salamatin, R. (2010). Hymenolepis diminuta: effect of infection on ion transport in colon and blood picture of rats. Exp. Parasitol., 124: 285-294.

Leong, T.S., Lim, B.L., Yap, L.F. and Krishnasamy, M. (1979). Parasite fauna of the house rat Rattus rattus diardii in Kuala Lumpur and nearby villages. Southeast Asian J Trop Med Public Health, 10: 122-126

Levi, M.H., Raucher, B., Teicher, E., Sheehan, D. and McKitrick, J. (1987). H. diminuta: one of three enteric pathogens hymenolepiasis isolated from a child. Diag. Microbiol. Infect. Dis., 7(4): 255-259.

Macko, J.K. and Hanzelova, V. (1997). Calixolepis Thuli N. G., N. Sp. (Cestoda: Hymenolepididae) From The Wood Duck Aix Sponsa (Anatidae) In America. Syst. Parasitol., 38: 137-145

Mahmoud, S.N. (1974). Incidence and distribution of helminth parasites of the digestive tract rats and mic of the family Murida in Baghdad area. M.Sc.thesis, Coll. Sci., Baghdad :153pp .

Mckay, D.M., Halton, D.W., Johnston, C.F., Fairweather, I. and Shaw, C. (1990). Hymenolepis diminuta: changes in intestinal morphology and the enterochromaffin cell population associated with infection in male C57 mice. parasitology 101: 107-113 .

Medway, (1983). The Wild Mammals of Malaya (Peninsular Malaysia) and Singapore, Second edition reprented with corrections, Oxfors Univ. Press, Kuala Lumpur, 131pp.

Mészáros , F., Habijan, V. and Mikes, M. ( 1983 ). Parasitic nematodes of rodents in Vojvodina (Yugoslavia). Parasitol Hung. 16, 103 - 109.
Miafiana, C.F., Osho, M.B. and Samwobo, S. (1997). Gastrointestinal helminthparasites of the black ratRattus rattus in Abeokuta, Southwest Nigeria. Journal of Helminthology, 71 (3): 217-220.

Miyazaki, V. (1991). Helminthic zoonoses. International Medical Foundation of Japan, Tokyo, 494 pp.

Mohammad, M.A. and Hegazi, M.A. (2007). Intestinal permeability in Hymenolepis nana as reflected by non invasive lactulose/mannitoldual permeability test and its impaction on nutritional parameters of patients. J. Egypt. Soc. Parasitol., 37(3): 1-16.

Nama, H.S. and parihar, A. (1976). Quantitative and qualitative analysis of helminth fauna in Rattus rattus. J. Helminthol., 50, 99-102.

Namue, C. and Wongsawad, C. (1997). A survey of helminth infection in rats ( Rattus spp.) from Chiang Mai Moat . South Asian J. Trop. Med. Publ. Hlth., 28: 179-183

Palmer, J.M. and Castro, G.A. (1986). Anamnestic stilmulus-specific myoelectric responses associated with intestinal immunity in the rat. Am. J. Physiol. 250: G266-G273.

Panpiglione, S., Visconti, S. and Pezzino, G. (1987). Human intestinal parasites in subsahran Africa II. Sao Tomes and Principe. Parasitologia 29: 15-25.

Paramasvaran, S., Sani, R.A., Hassan, L., Kaur, H., Krishnasamy, M., Neffery, J., Raj, S., Ghazali, S.M. and Hock, L.K. (2009). Endo-parasite fauna of rodents caught in five wet markets in Kuala Lumpur and its potential zoonotic implications. Tropical Biomedicine. 26(1): 67-72.

Payne, J., Francis, C.M. and Phillipps, K. (1985). A field guide to the mammals of Borneo. The Sabah Society with World Wildlife Fund Malaysia, Kota Kinabalu.

Podesta, R.B. and Mettrick, D.F. (1974). the effect of bicarbonate and acidification on water and electrolyte absorption by the intestine of normal and infected (Hymenolepis diminuta, Cestoda) rats. Amer. J. Dis., 19, 725 - 735.

Sadjjadi, S.M. and Massoud, J. (1999). Helminth parasites of wild rodents in Khuzestan Province, Southwest of Iran. J. Vet. Parasitol., 13: 55-56. 
Seong, J.K.; Huh, S., Lee, J.S. and Oh, Y.S. (1995) Helminth in Rattus norvegicus capture in Chunchon, Korea. Korean J.parasitol., 33(3). 235-237 .

Simmons, D.J.C. and Walkey, M. (1971). Capillaria and Hymenolepis in a wild rat: Hazards to barrier - maintained laboratory animals. Laboratory Animals. 5: 49-55.

Singla, L.D., Singla, N., Parshad, V.R., Juyal, P.D. and Sood N.K. (2008). Rodents as reservoirs of parasites in India. Integrative Zoology. 3: 21-26.

Stojcevic, D., Mihaljevic, Z. and Marinculic, A. (2004). Parasitological survey of rats in rural regions of Croatia . Vet. Med . Czech, 49:70-74 .

Syed Arnez, A.S.K. and Mohd Zain, S.N. (2006). A Study on wild rats and their endoparasite fauna from the Endau Rompin National Park, Johor. Malaysian J Sci., 25:19-39

Webb, R.A., Hoque, Tand Dimas, S. (2007). Expulsion of the gastrointestinal cestode, hymenolepis diminuta by tolerant rats: evidence for mediation by a Th2 type immune enhanced goblet cell hyperplasia, increased mucin production and secretion. Parasite Immunol. 29: 11-21.

Yamaguti, S. (1959). Systema Helminthum. Vol. II- Cestodes of Vertebrates. Inter. Science Publishers Inc. New York

Yen, C.M., Wang, J.J., Lee, J.D., Chen, Y.P. and Chen, E.R. (1996). Parasitic infections among wild rats from two areas of Kaohsiung. Kaosiung J: Med. Sci., 12, 145-149.

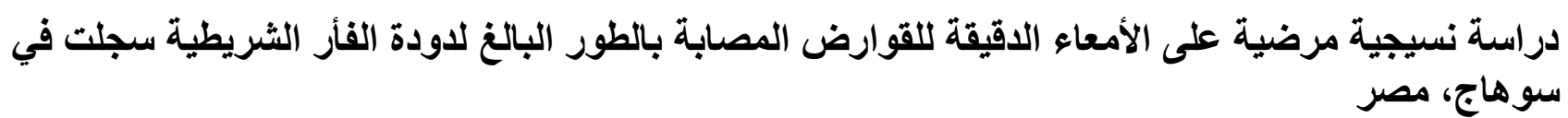

$$
\text { - الهام فرغل عبد الجو اد }
$$

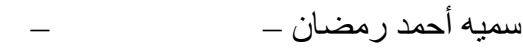$$
\text { قسم علم الحيوان - كلية العلوم - جامعة سوهان }
$$

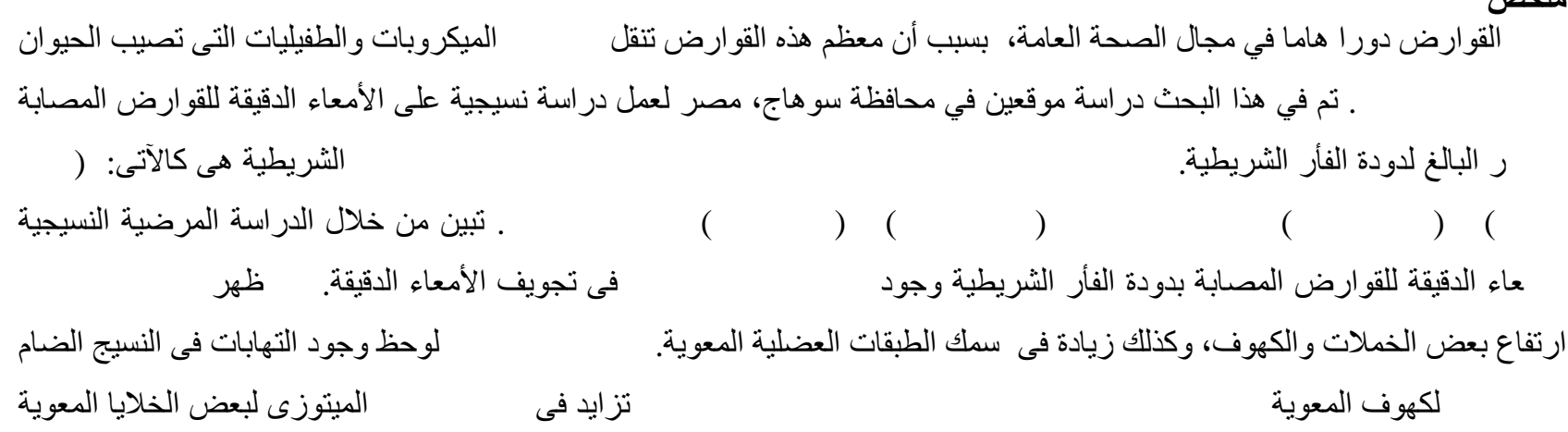

